
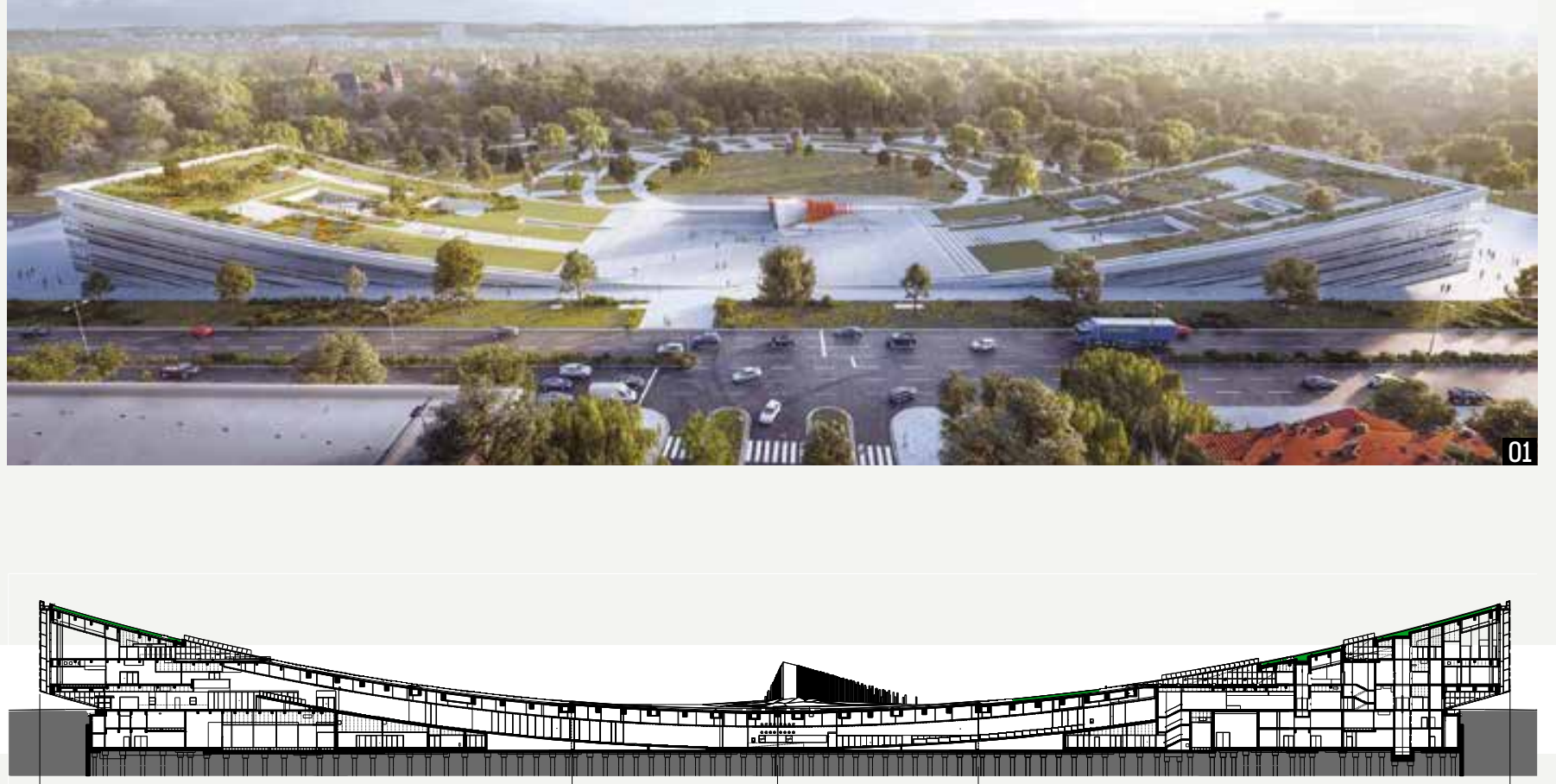

02

\title{
AZ ÚJ NÉPRAJZI MÚZEUM CSAPADÉKVÍZ-ELVEZETÉSE
}

\begin{tabular}{|c|c|}
\hline 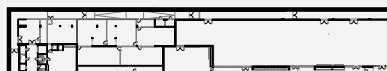 & $7 \sqrt{-12}$ \\
\hline 臯 & 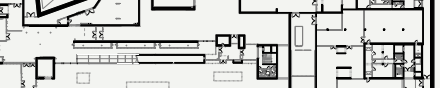 \\
\hline
\end{tabular}

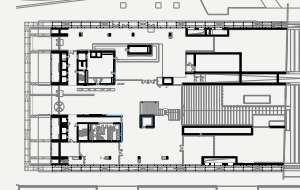

04

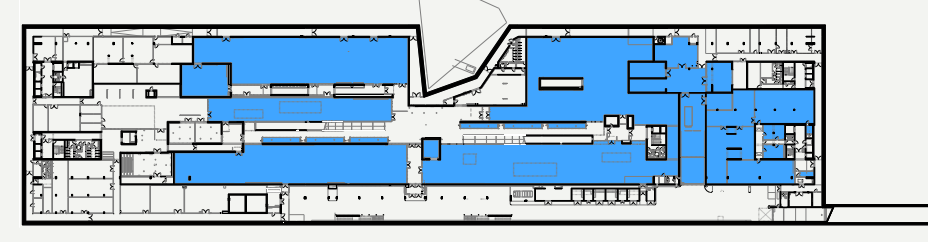

05

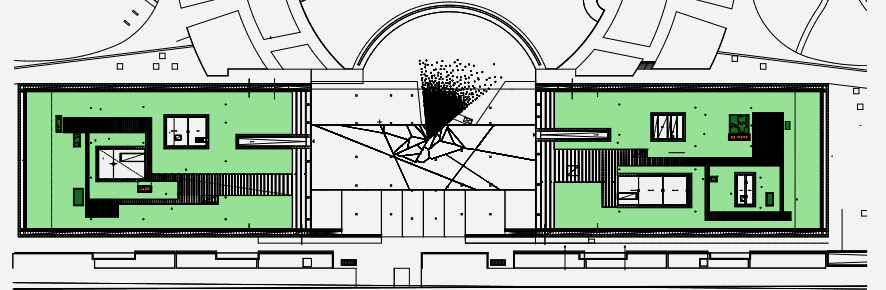

06

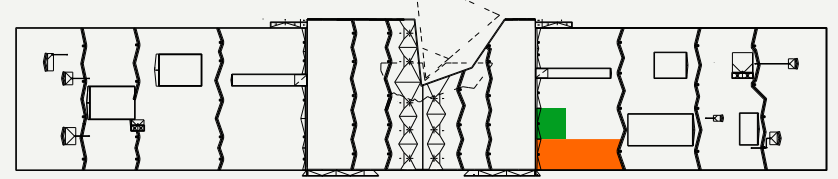

07

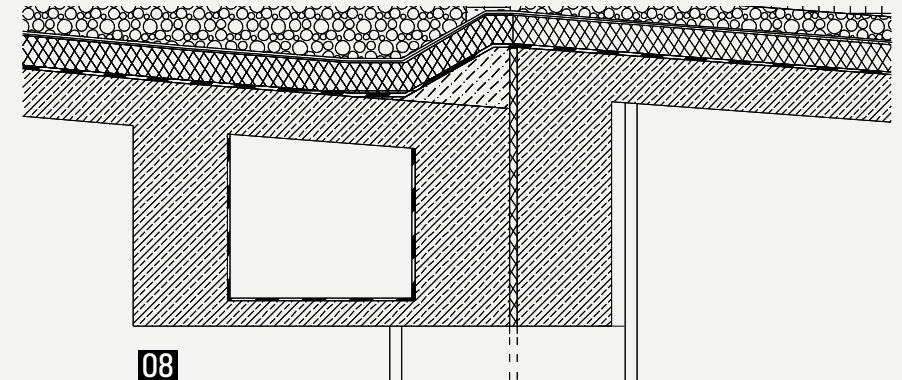

01 Látkép a Várossligeti fasor irányából Az épület hosszmetszete, a dilatációs szakaszok jelölésével
Pinceszint alapraiza

04 Földszint alaprajza

$05 \quad$ Fokozottan védendỏ mútárgyi és kiâllitóterek

$06 \quad$ Tetỏkert elrendezési rajza: világoszzöld - zöldfelület, sötétzöld favermek, narancs - hỏ- és füstelvezető aknák

07 Lejéskép és vízterelő ó́tak, szokísos vízgyuyútón terület zöld, narancsszínnel

08 Tartószerkezet síkváltási részlete szerkezeti dilatáció mellett, gépészet szerelótérrel

\section{BEVEZETÉS}

- Az Uj Neprajzi Muzeum a Városliget történelmi bejáratában, a Varosligeti fasor és Dozzsa Gyorgy thtakloziser kapuzart léptékú tetókertet hoz létre az 56 os emlékmú két oldalán. [I] Az esettanulmanyy tárgya a metszetében és részleteiben külonleges vârosi tér és tetókert múszaki megoldâsa, a megvalósitás egyedi részletel.

A TERVEZÉS PEREMFELTÉTELEI - A különleges építészeti koncepcio miatt az épuletszerkezeti tervezés nem hagyatkozhatott jaratos módsze rek adaptalassára. [2] Elvi alapoktóo kiinndulva kellett vizsgalnir a lehetseges múszaki megoldásokat. A spe62 metszet 2020/6 Épúletszerkezzettan rôvid átfutási ideje is kihívást jelensőszigetelési müszzaki koncepcót kellett kialakítani, amely függeten a rákerüló rétegektổl, szabad tere ad a tető́kert épitészeti formálására a lehető legkésőbbi időpontig. _ A szabad formálás igénye érintette Z I956-os forradalom emlékműve elótt elterûlô, kis kockakó burkolatí, .felgyưródoô" térplasztikát is, amelyet aterszin alatti beepités miatt el kellett bontani. Az alkotás ezen részét az emlekmüvet alkoto I-Ypszilon csoport - Horvâth Csaba képzomúvész Dósa Papp Tamás építész, EmőoliKiss Tamás épitész és Gyơrgy Kata képzomúvész - az uj terri osszefungge ekre reagálva, a tervezsi projektte párhuzamosan haladva átfogalmazt
—A vizelvezetési rendszert êrtelemszeruen a zarofododem alatti funkciokhoz kellett illeszteni. A belső tere epiteszeti koncepciója heterogen struktúrann alapult, amelyben szabàlytalanul elrendezett vasbeton magok hordják az alulbordàs monolit vasbeton fodémeket. A szintek szabálytalan, helyenkent konzolos belso konturral tôltik ki a fold alol ivesen feltôro epületet. Ennelfogva a több mint 30000 m² haszrnos alapterulet minden szeglete alaprajzi ertelemben egyedi. — Az egyediség a szerkezeti dilatációk kiosztásában is megjelent, mive a struktúra kevés cészerú helyzetet kinalt fel. Az epulet felszín feletti. tobbszintes szárnyai igy 100-100 m hosszú dilatációs egységet alkotnak ami a csapadêtrizedvezetes szempontjából előnyt jelentet.
$450 \mathrm{~m}^{3}$-es befogadót a közmúadottságok és meglévỏ növényzet miatt teljes egeszeben a Rondo alatt kel- Amuzeum, az alapterület nagyobb részé̉enen, egyetlen fold alati szintbólall. A nutangyak biztositási követelményei miatt a vizes rendszerek vezetekei nim hi nak kiállitó- és mútárgyraktározási terek felett, amelyek az epuilet jeler tos reszet teles szélességben kitöltik. Ez azt eredményezte, hogy ezen a területen a zárófödémet elvben nem lehetett áttörni csapadékvíz-elvezetéssel és csapadékvíz-gerincvezetéket sem lehetett keresztülvezetn az épületen.

- A csapadekvizet a közcsato na-halozat tulterheltsége miatt nem lehetett elvezetni még zaportároz közbeiktatásával sen. Atalajszerkezetnek koszonhetoen viszon szikkasztót lehetett létesiteni. lett kialakítani. Az esetenként magas talajvízszint jelentősen korlátozta a csatlakozasi mélységet, igy az epiletből lejtésben kivezetett nyomvonalak hosszátis. Ez azt eredményezte hogy a kivezetéseket a Városliget felôli homlokzat mentén kellett elhelyezni.

A VíZELVEZETÉS GEOMETRIAI PEREMFELTÉTELEI

— A tetőfelület metszetében egy szabályos hengerfelületet követ, amelynek legnagyobb lejtése a vég homlokzatok mintent 16,22, azaz 29,091\%. A könnyebb kivitelezhetốség érdekében, a lejtésre merỏlege gerendák között a zárófödém mezôi sik lemezek 3 - $6 \mathrm{~m}$ fesztávolsággal. - Atetorelületet az egyes szintek- A csallakozo kijaratok, vizszintes teraszok, valamint a tetofelületbe

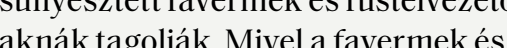
anák tagoljak. Mivel a favermek és aknák tenszintje a gerincrezetésüllyed, ezérto almennyezeti tér al

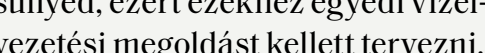
Az emlékmú térplasztikája speciális geometriai elemként jelent meg a tervezésben. Az új..felgyưrő́dés" 2,4 m magasságba tör fel a kapcsolódó térszínhez képest, szobrászati igényességú részletekkel. Az épü let strukturajaatol független installációval szemben müszaki elvárás vol, hogy a lehetó legkönnyebb legye miközben nem torzulhat, nen 

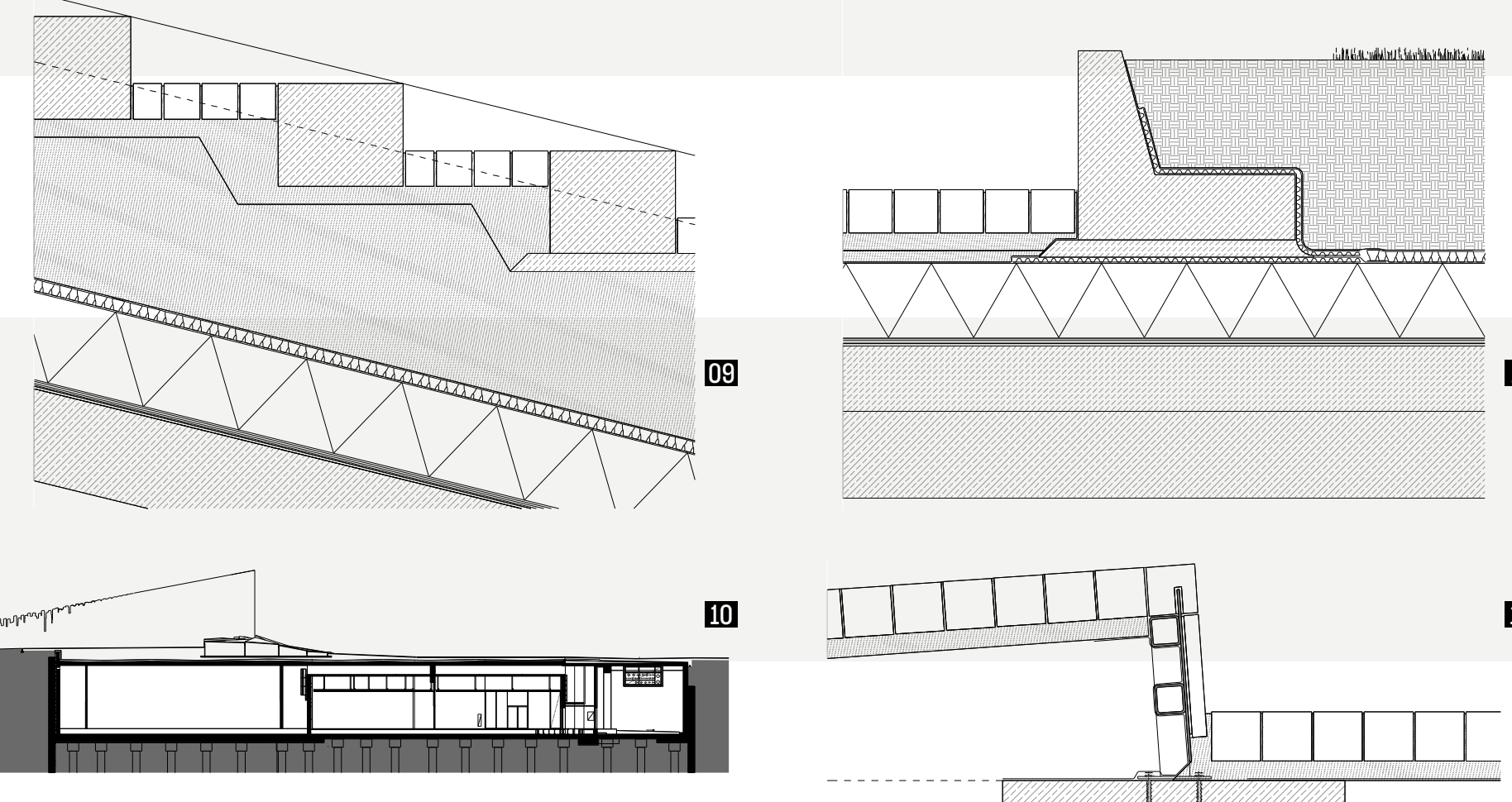

09

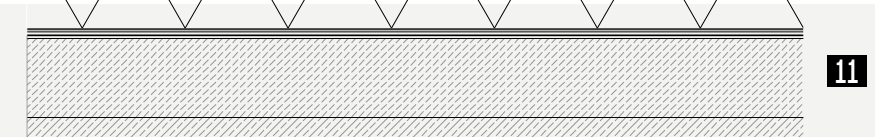

11

10

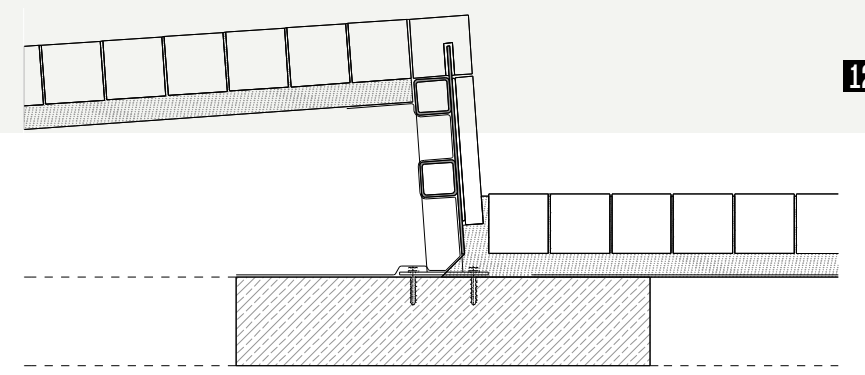

09 Lépcsőzzetes burkolat kialakitásának részlete

10 Teraszok növénykádjának részlete

11 Metszet az emlékmú burkolatplasztikáján keresztui

12 A burkolatplasztika részlete

12

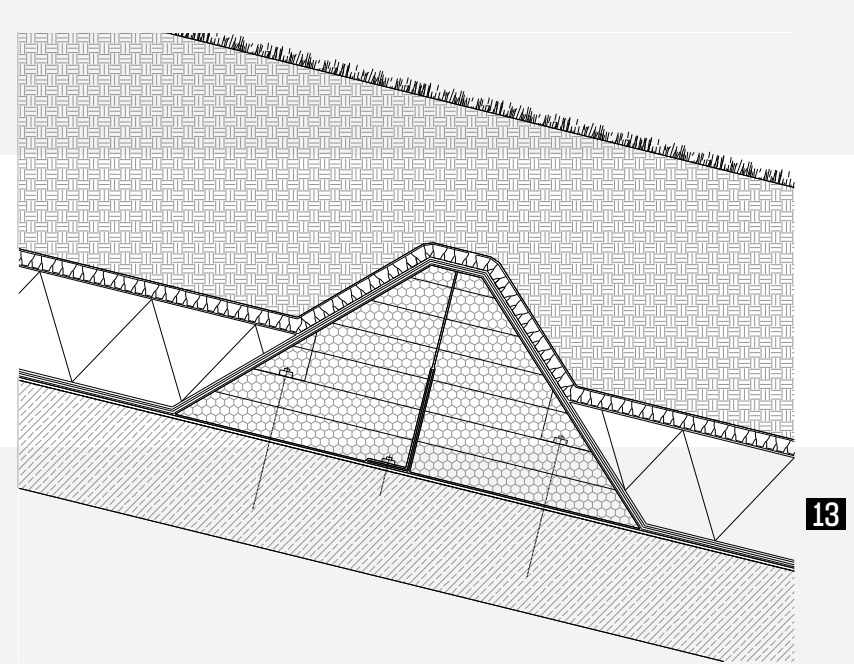

13

14
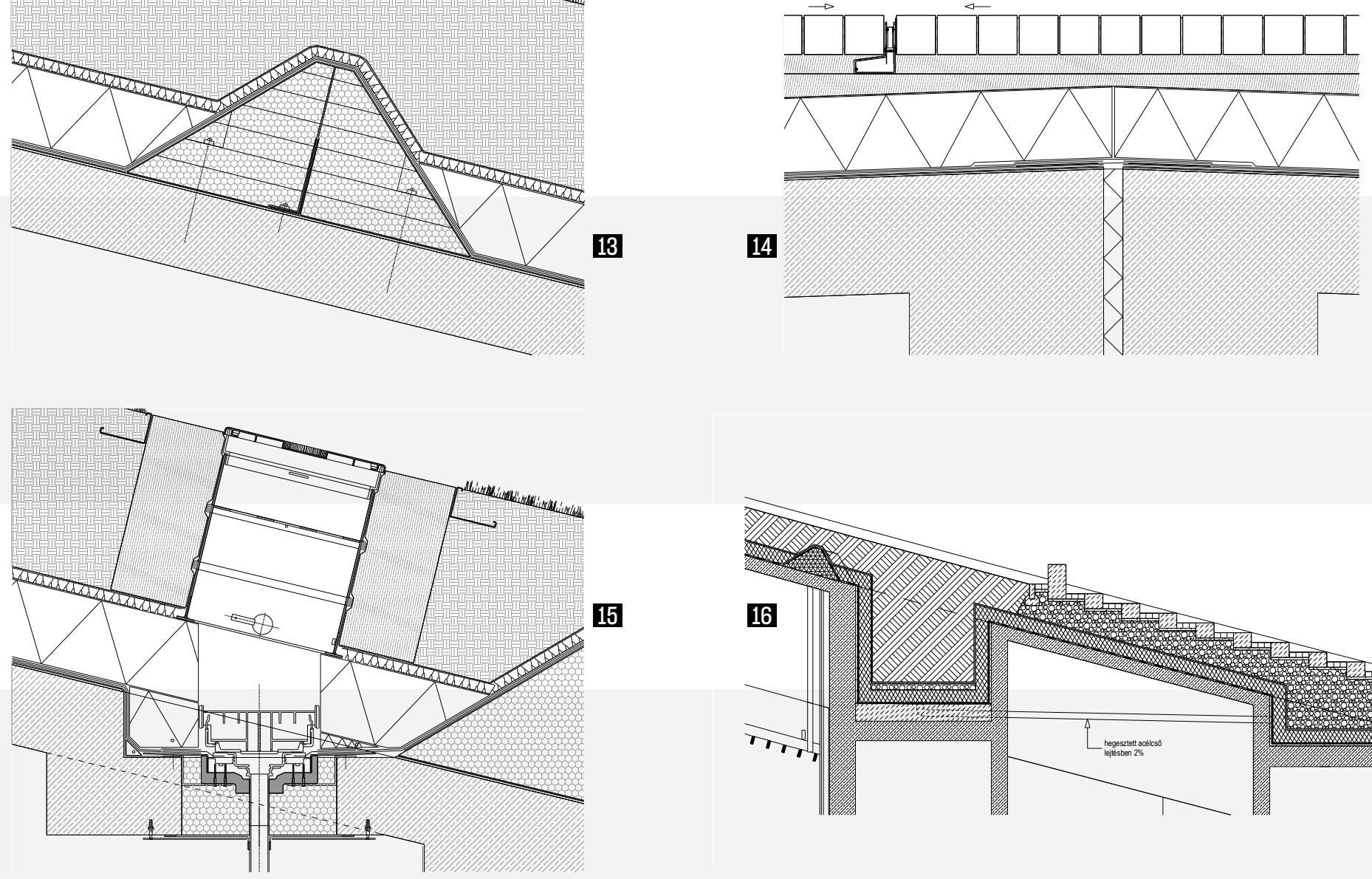

15

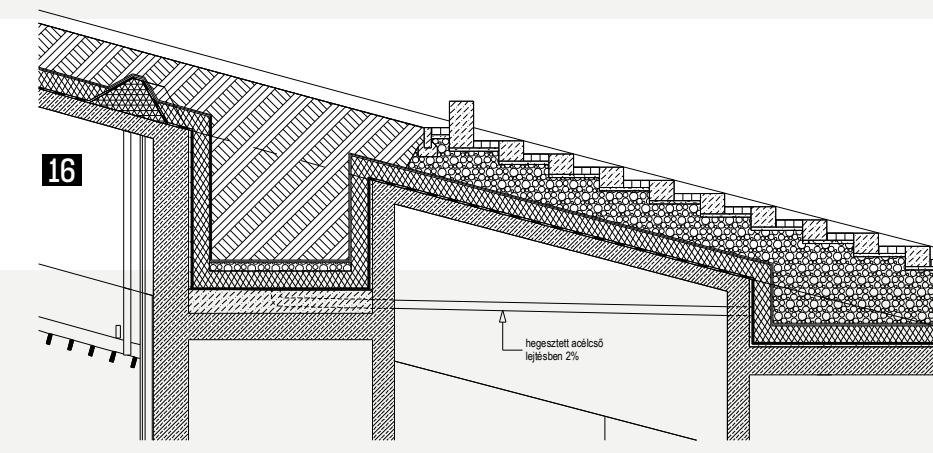

roskadhat, és a lehető legpontosabb kivitelezést kell lehetóvé tegye. [3]

\section{A TERVEZÉS METODIKÁJA}

— A peremfeltételek ismeretében

több szálon folyt a tervezés:

- el kellett készíteni azt a hỏ-és csapadékviz elleni szigetelési koncepció

a tetơfelületre, amely a megfogalmazott rugalmassaggal tudta követni az építészeti tervezést;

megoldást kellett talălni a csapadékviz-gerincvezetékek nyomvonlának kialakítására a kiállítóterek felett olyan módon, hogy az biztosítás szempontból megfelelő legyen; - a favermek vizelvezetésennek keze lésére egyedi, hosszú távon üzembiztos müszaki megoldást kellett megalkotni;

- meg kellett hatarozni a befogadó irányából az épületen belüli lehetséges csapadékvíz-csatorna nyomvonalakat;

- ki kellett dolgozni az emlékmú térplasztikájának irányadó mủszaki megoldását.
A CSAPADÉKVÍZ-ELVEZETÉS RENDSZERE

- Az 51,00 x 291,60 m-es tetó I6500 $\mathrm{m}^{2}$-es felületén az iránvelvek szerin több mint I30 összefolyót kellett voln elhelyezni, súlyosbitva azzal, hogy az egy iranyba lejtó felületen egy összefolyó körül a víz útja csak az egyil a vízelvezetés szempontjából előnyös igen meredek lejtésre, a lejtéshoszszakat duplájára növeltük, a szigetelési rétegek teljesitményének növelése mellett. Az attorések számának csöol hálózat kialakitása érdekében tel szer mellett döntöttüunk, a vízgyüjtő felületek maximális nagyságát 400 $\mathrm{m}^{2}$-re növelve.

- Vapacsatornak kialakítására nem volt szerkezeti lehetőség, így a vízelvezetest pontra lejtésekkel kellett megoldani. Az ellenlejtesek hagyom nyos kialakitàsannak korlátja az volt, hogy az epiteszzeti szabadság biztostàsa erdekében a tetörétegrend még lokálisan sem lehetett vastagabb az irányból értelmezhetỏ. Tekintettel kentese, illetve a gazdasagos belso szelvényủ csapadékvíz-elvezető ren âltalános felületnél. A teljes rétegfelepités vastagságat korlatozták a be magassági igények, valamint a $20 \mathrm{~m}$ feletti fesztávolságú tartószerkezetek racionális terhelhetősége. — A víz közbensỏ megállítására és elvezetésére így geometriailag és tett tervezesi ütemezési körülménye miatt nem jelenik meg a burkolat vagy zöldfelületi rétegek felett. _ Az épuleten átfuto harom szerkiemelése fel sem merülhetett a ker egységes látvanny vilàga milatt, igy az azok elôtti vizzelenitest és a biztons gos szigetelésatvezetést a rétegrendben kellett megoldani. _ A felületek vizsgálata alapján egy egyenesekből álló poligon mentén epitett, egyseges keresztmetszet vonal menti szerkezet lett a pontr lejtés múszaki megoldása. A poligon magaspontjai a vizgyúítón terüle tek hatarrpontjai, a mélypontok pedig maguk az összefolyók. szerkezeti részleteiben is egyedi me oldást kellett tervezni, ami az emlíkezeti dilatáció tetőfelületből való
- A tervezés viszonylag korai fázisában jóváhagyták, hogy az emlékmú eredeti múvészeti ko cepciójával összhangban az épület középsô területèn burkolt váro tér legyen. A hatärozott burkolatva tás felkinalta az elteroro rétegfelépítest egyben kijelölte az ideális szerkezeti dilatációk helyét is. Az emlékmú elótt így 2-8\%-os lejtésú tartoszerkezeten, szokvânyos lejtesképzés geometriával megoldhatóvá vá a pontra lejtések kialakitás - Az osszefolyok rendszerene és a víz pontra terelésének megoldása összefüggött a belso térben kínálkozo levezetési lehetóségek kel is. A szabálytalan alaprajzi strukturra még nem jelentett volna extrém kötöttseget, azonban a levezetése ket a vèdendó terek alaprajzi kiterjedese es a fent emlitett szikkaszto helye miatt csak a Varosliget oldalán lehetett kialakítani. A telt szelvényú csapadékviz-elvezetés gerincei a vizszintes nyonvonaluknak koszöneton a tovilibirendszerek akadályozása nélkül, a zárófödén gerendainak takarasában az e êu let teljes szêlessége mentén lehetett vezetni. Az összefolyók végleges pozícióit a lehetséges gerincvezeték-nyomvonalak, egységes nyomásszintek és megengedett maximalis vízgyuüjtőterületek alapján határoztuk meg.

Jôllehet a telt szelvényủ vízelvezetó rendszerek akár 400 m²-es vizgyujo felületeken is mukoodnek, azonban a biztonsagos mukoodéshez minimavizgy ujto feltulet 35 in. Aholeznen teljesult, ott gravitációs rendszert kellett kialakitani annak minden következmennyével. Ilyen vízelvezetest kellett letesiteni a kisebb mére teraszokon és a hố- és füstelvezetó rendszer aknáiban.

— Kezdettol fogva nyilvánvaló vol hogy összefolyók létesítése szükseges a kiallitoterek felett is, tekintettel a védett terület alaprajzi râst, egy ellenônzheto, zárt teret ke lett biztosítani az összefolyók é lis felületi kotottsegek is tartoznak A legkisebb elvezetéssel kialakítható kiterjedésere. Értelmezve az elvá- nyomvonalak alatt. Természetesen az epuilet geometriaja nem tette lehetôvé komplett szerelószint kialakí-

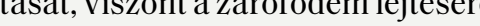
kínálta a lehetóséget arra, hogy gerendakettózéssel megfeleló szerelótereket lehessen kialakítani. Az ilyen mơdon kialakitott, I,20 m széles, alulról vasbeton födémmel határolt telés készült, megközelítésük alárendelt terek irányából biztosítot.

\section{A RÉTEGRENDEK}

A zárófödém felületén alapvetóen hat elterón rétegrendet kellet meghatározni.

- a tetókert zöldfelülete.

- a tetőkert burkolt felülete

- a vízszintes teraszok felülete,

- favermek,

- az emlékmủ előtti városi, burkolt

- emlékmủ térplasztika.

— A zöldtetóo és a jelentỏs hasznalati terhelésnek kitett burkolt feliletek miatt általánosan fordítot merőleges gerendarendszer felszerelócsatornákba kảrmento szige- 


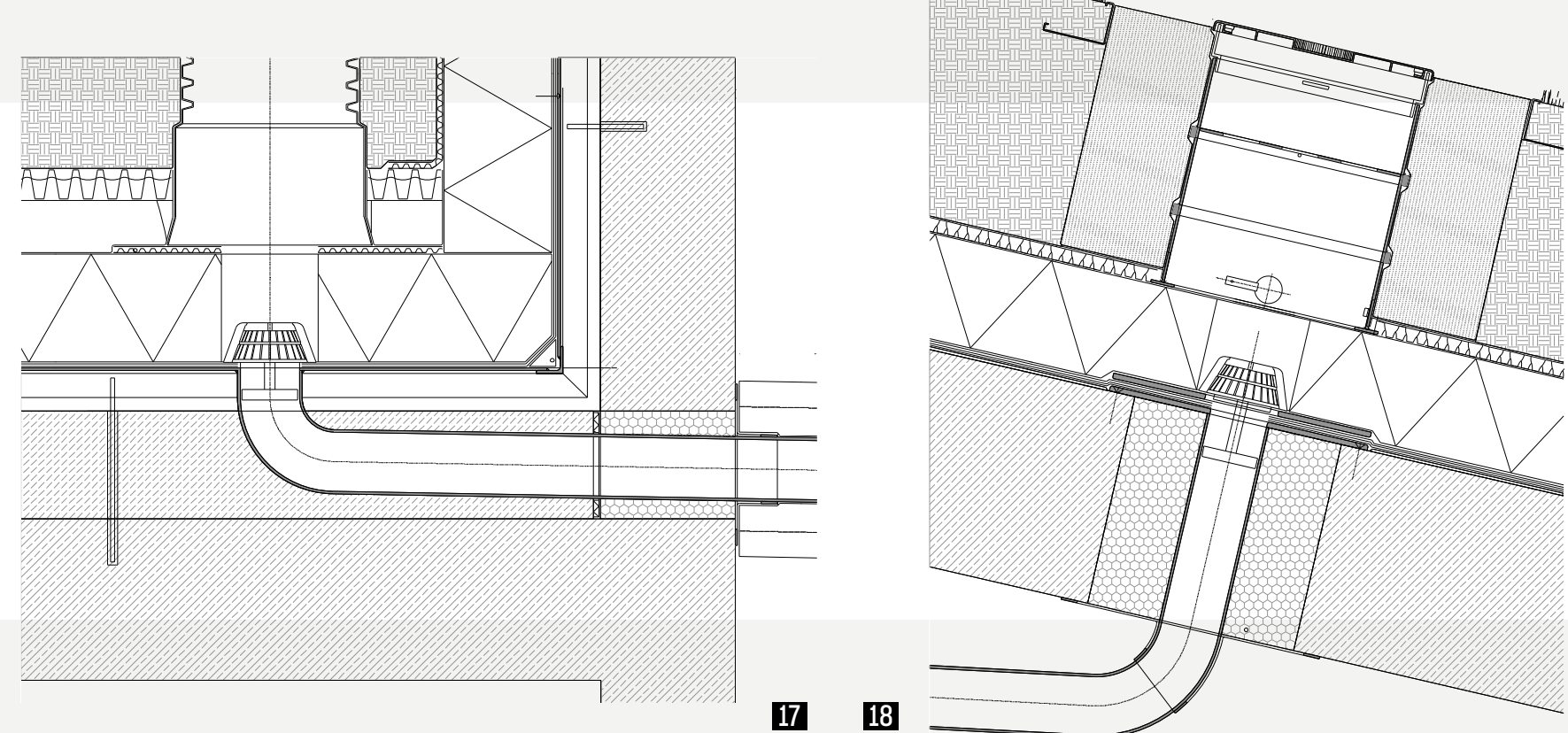

$17 \quad 18$

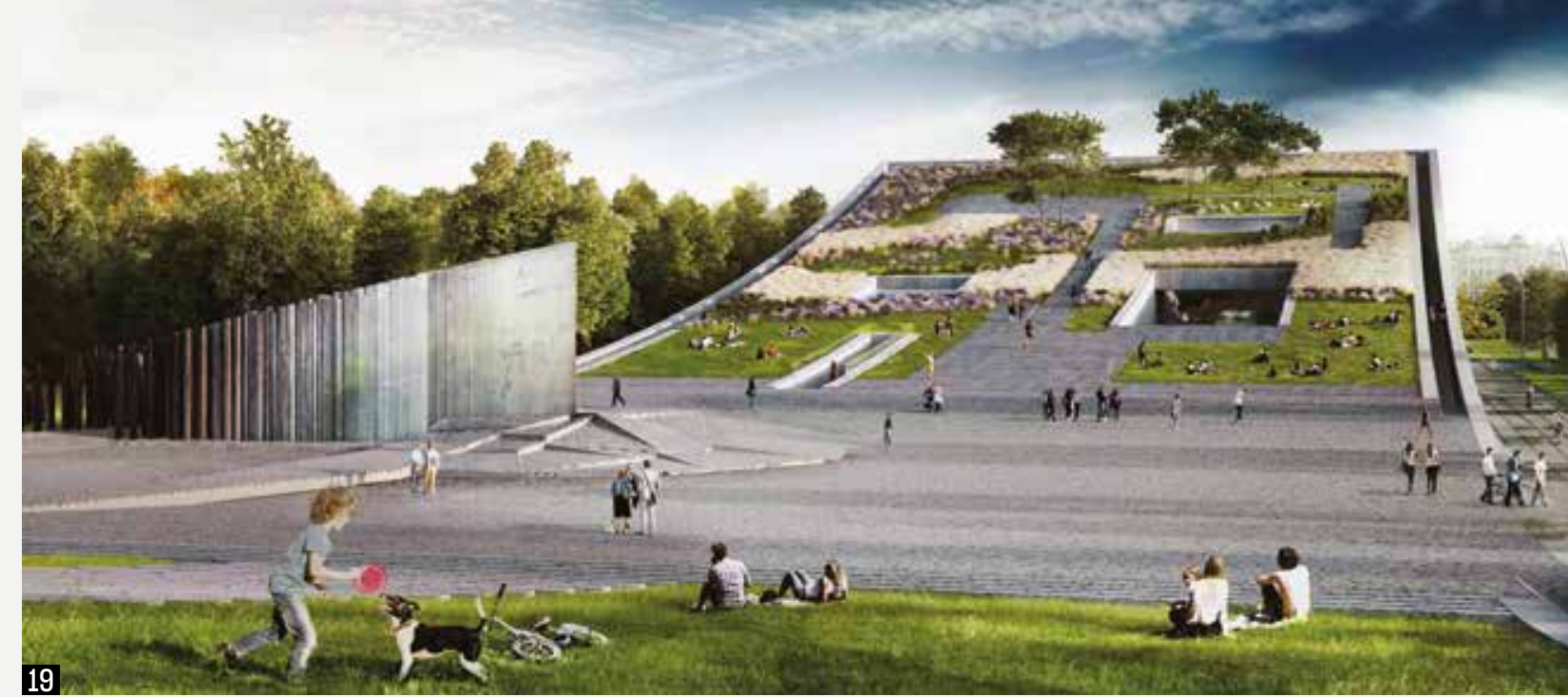

IRODALOM/ REFERENCES

[1] „Néprajzi Múzeum a Városligetben”, Octogon, Issue 140 (2017/8), pp 86-89.

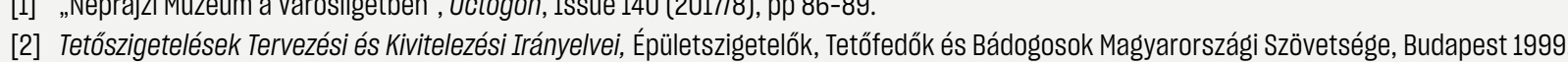

[3] Zöldteteốk Tervezési és Kivitelezési Irányelvei, Épületszigetelö́k, Tetớfedók és Bádogosook Magyyarországi szövetsége, Budapest 1999.

ÉpíTÉSZ: Ferencz Marcel, Détári György (Napur Architect Kft.) | ÉPÜLETSZERKEZETEK: Reisch Richárd (FRT Raszter éṕtész iroda kft.) | ISTATIKA: Szántó László (Exon2000 Kft.) | GÉPÉSZET: Lucz Attila (HVArc Kft.) I TÁuÉṔTTÉSZET: Steffler István (Garten Studio Kft.)
_- A bitumenes lemezek fektetési technológiája miatt $45^{\circ}$-os ékelemeket terveztünk $15 \mathrm{~cm}$ túlnyúlással a hőszigetelés felső síkján. Anyaguknak a hőszigetelő tulajdonsággal bíró purenitet válasz tottuk, ami egyben alkalmas aljzat a bitumenes csapadékvíz-szigetelés számára. A $45^{\circ}$-os kialakítás és az ékelem felso elennek vízszintes lecsapása a vízszigeteló lemezek folyamatos, törésmentes fektetését teszi lehetővé. Annak érdekében, hogy a purenitelemek közé bejutó para ne tudjon feldúsulni, a tetószigetelési retegek atfutnak az ékesíkot alkotja. A vízterelő esésvonalla bezart szoge a metszeti körív mentén változik a vápákban szükséges minimális esés szerint. - Adilatációk elótti pontra lejtéseket a rétegfelépítés vastagságváltás réven konnyubeton lejtésképzéssel ki lehetett alakítani. A födémszerkezet szintugràssal készült a célszerủ vasalàs és erojăték miatt. A dilatáció így a vizszigetelés szempontjábó szimmetriatengelyben lévő dilatáel, azonban az összefolyók koo dinálása révén itt is magasponti lem alatt, a vizterelő tetejére kerüló lemez pedig a tenyleges szigetelés magasponton fut végig. A harmadik, ció is takart helyzetben helyezkedik helyzetben, jóllehet minimális $2 \%$-os lejtések között.

_ A pontszerủ összefolyók kialakitása a változó lejtésủ felületen egyed tartószerkezeti megoldást igényelt. A telt szelvényú csapadékvíz-elvezető rendszerek fejeit az elváı működés érdekében vízszintesen kell beépiteni. Mivel az összefolyóknak mélyponton kell elhelyezkednic, ezért a szigetelés toldásainak kialakitásához is elegendő felületủ vízszintes szakaszokat 6ox6o cm-es süllyesztékként alakítottuk ki. - Afavermek felett vizterelóket terveztünk, hogy ne halmozódjon fel bennük a felsőbb területekről össze gyủló víz, károsítva a fákat. lgy azonban felmerült, hogy a jelentős vastagságú, nagy vízfelvételü ültetőközegre tekintettel a csapadékviz eljuthat-e a vizszigetelés síkjáig figyelembe véve a felületi párolgáson túl a beültetett fák vízfelvételét is. A fák pótlásának bizonytalansága és a vizszigetelés felett lévo hooszigeteló reteg szüksseges víztelenítése miatt

mellett döntöttünk.

— A favermek fenékszintje és lakozási, valamint nyomvonalvezetési korlátok miatt a vizelvezetésr gravitációs rendszerrel nem végül a csapadékvizek elvezetése a korábban részletezett közmúcsat kínálkozott célszerủ megoldás. Emellett a leszivárgó víz bizonytalan mennyisége miatt telt szelvényû rendszer beépitése sem tủnt lehetségesnek. Ekkor fogalmazódott meg a gondolat, hogy a vizet tereljük vissza a tetôfelületre, ahol utat talál egy alkalmas elvezető rendoldás egy rozsdamenetes acélcső közlekedőedény. A kivezetési pontok a veremben ne tudjon összefüggö lés soha ne lehessen víz alatt.

\section{ÖSSZEGZÉS}

—A feladat összetettségéhez merten rendkivül szủk határidó ellenére a tervezési folyamat az ütemezési perencelételeketis szem elổtt tartó metodikának köszönhetóen határidóben, sikeresen zárult. Reményeink szerint a tervezett müszaki megoldások hosszú távon is kiállják az idő próbáját, méltón az egyedi, rangos épülethez. szerhez. A tervezett múszaki megolyan szinten helyezkednek el, hogy vizfelület kialakulni, es a hószigeteség ne bukhasson át a terelő felett, a folyóját terhelve. 


\section{ABSTRACTS}

MIZSEI, Anett: WELL WORKING MACHINERY TO CONTEMPORARY ART Citation: Metszet, Vol17, No 6 (2020) pp 8-15. DO1. 10.33268/Met 2020.67 AQUATICUM STRAND, DEBRECEN, HUNGARY / Architect PÉTER BORDÁs $\begin{array}{ll}\text { to create a sustainable building complex. } & \text { upwards to create water slides, fountains and } \\ \text { other architectural features. Bravely placed }\end{array}$

bridges accentuate the sculptural aspect of
this design. Planting also plays an importan role in this scheme with green roofs and vertical planted walls.

KATONA, Vilmos: KOOLHAAS AND THE KOREAN WONDER WEAPON Citation: Metszet, Vol 11, No 6 (2020), pp 16-21, DOI: 10.33268/Met.2020.6 2 MKOOLHAAS hat fuse commercial and cultural activities a parametric sase study. Is this project to be

Ilimits of what can be transferred from digital within psychological constraints possibly

\section{WARE-NAGY, Orsolya: BIG OFFICE, BIG TOWN, BIG PROJECT}

Citation: Metszet, Vol 17, No 6 (2020), pp 22-27, DOI: 10.33268/Met.2020.6.3

SILK ROAD INTERNATIONAL CONVENTION CENTRE, XI'AN, CHINA | Architect: MEINHARD von GERKAN, NIKOLAUS GOETZE and MAGDELENE WEII

The size of this building is hard to visually the refined use of structural and curtain wall accuracy of detailing steelwork and BIM elements. Detailed to seemingly float above working methods. Initially a period of 300 days was expected to reach structural completion,
this was achieved in 90 days. Prefabrication being the key to success.

\section{FUNK, Bogdán: TROPICAL TEACHING MACHINE}

Citation: Metszet, Vol 17, No 6 (2020), pp 28-33, DOI: 10.33268/Met.2020.6.

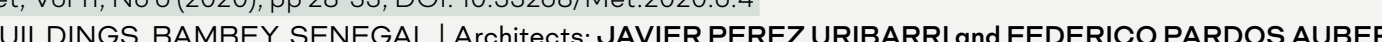

$\begin{array}{lll}\text { Inspired by the existing landscape and } & \text { reworking of LeCorbusier's Machine for Living. } & \text { treatment systems. The core of the building } \\ \text { trees the new university buildings have } & \text { Unlike machines this building employs its built } & \text { working like a tree trunk supporting the canopy } \\ \text { been designed to work in harmony with } & \text { form as a shading device, and temperature } & \text { like roof. } \\ \text { the environment creating a metaphorical } & \text { control, rainwater management and waste } & \end{array}$
the environment creating a metaphorical control, rainwater management and waste

WESSELEENYI-GARAY, Andor: STRUCTURE AS ORNAMENT Citation: Metszet, Vol 11, No 6 (2020), pp 34-39, DOI: 10.33268/Met.2020.6.5 Restoration Architects: MARGEL FERENCZ and GYÖRGY DÉTÁR

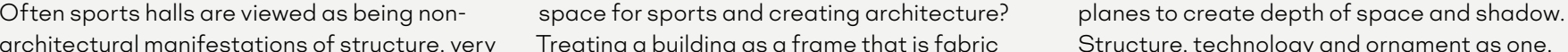
$\begin{array}{llll}\text { architectural manifestations of structure, very Treating a building as a frame that is fabric } & \text { Structure, technology and ornament as one. } \\ \text { little soul with little in terms of character. So } & \text { covered or, as in this case treating structural What is allowed? What are we used to? What }\end{array}$ $\begin{array}{ll}\text { little soul, with little in terms of character. So } & \begin{array}{l}\text { covered or, as in this case treating structural } \\ \text { coverings as a graphical tool: extruding }\end{array}\end{array}$

\section{CSANÁDY, Pál: EXTRA MUROS}

Citation: Metszet, Vol 11, No 6 (2020), pp 40-45, DOI: 10.33268/Met.2020.6.6

MARKET HALL, PÁPA, HUNGARY | Restoration Architects: CSABA NÉMETH and FERENC PENG

As with many larger towns in Hungary $\quad$ hall encloses covered permanent market pavilions. What sets this project aside

terminus. To replace this a competition was side, administration offices and public $\quad$ galvanized steel, pergola.

\section{NÉMETH, CSABA: KEF-ILK IN SZABOLCS UTCA}

Citation: Metszet, Vol 11, No 6 (2020), pp 46-49, DOI: 10.33268/Met.2020.6.7

former hospital buildings dating back to 1908 , character in a suitable manner for the

$\begin{array}{ll}\text { redevelopment as a modern office building } & \text { guncenfield development that has a good visual }\end{array}$

tion to the former hospital building that compliments the OMRRK buildings on the

PATAKY, RITA: Thoughts on developing the sloping roof and insulation

Citation: Metszet, Vol 11, No 6 (2020), pp 50-55, D DOl: 10.33268/Met.2020.6.8

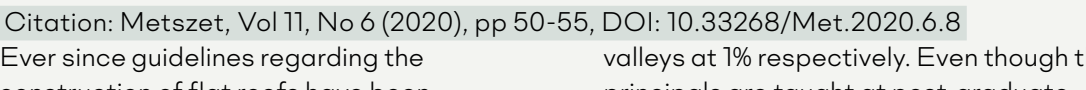

construction of flat roofs have been principals are taught at post-graduate

$\begin{array}{ll}\text { firloduced it is well known that roofs must } & \text { level, the task seems routine, however } \\ \text { experience shows that practice is often more }\end{array}$

ex. The article about Budapest One

BIRGHOFFER, PÉTER: RECONSTRUCTION OF THE HORSE-RIDING HALL ON BUDA CASTL

Citation: Metszet, Vol 11, No 6 (2020), pp 56-61, DOI: 10.33268/Met.2020.6.9

In professional aircles interest in this Horse- technology has been aroused. After all, it is roof, it is the idea of employing contemporary
DÉTÁRI, GYÖRGY - REISCH, RICHÁRD: RAINWATER DRAINAGE AT THE NEW ETHNOGRAPHIC MUSEUM Citation: Metszet, Vol 11, No 6 (2020), pp 62-67, DOI: 10.33268/Met.2020.6.10

the historic entrane to City Park The subject drains above and rouf garden. The number of reduced, and the design process completed reduced and the water had to be drained. The mind the edge conditions.

KOVACS, KAROLYLEHEL-REISCH, RICHARD.INSULATION CHALLENGES OF PARAMETRICALLY DESIGNED ROOF SURFACES Citation: Metszet, Vol 11, No 6 (2020), pp 68-73, DOI: 10.33268/Met.2020.6.11

Sou Fujimoto, the Japanese arohteot, requiring new engineering solutions. This concepts precisely defined and design stages, $\begin{array}{lll}\text { imagined the House of Hungarian Music at } \\ \begin{array}{l}\text { City Park. The building's roof geometry goes } \\ \text { against traditional design methods, which }\end{array} & \begin{array}{l}\text { article shows the structure via parametric, } \\ \text { computer assisted modelling, a double curved } \\ \text { shell's water proofing and insulatation. Technical }\end{array} & \begin{array}{l}\text { the development of the details. Summary of } \\ \text { reasons and suggestions regarding changes } \\ \text { made during the construction period. }\end{array}\end{array}$

FÉLIX, ZSOLT - KAPOVITS, GÉZA: LESSONS FROM AN OFFICE BUILDING

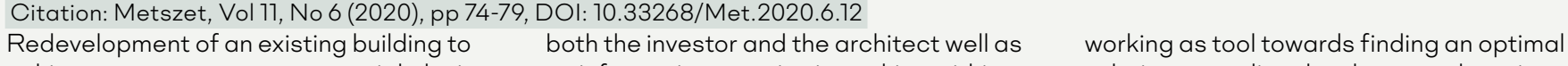
$\begin{array}{ll}\begin{array}{l}\text { achieve contemporary commercial, design } \\ \text { and environmental standards has served }\end{array} & \text { a informative exercise in working within } \\ \text { a given, built, framework. Architecture } & \text { solution regarding development, location } \\ \text { and continued facility management ideals. }\end{array}$

\section{HEINZ, DÁNIEL - KAPOVITS, GÉZA: SAINT MARGIT GYMNASIUM}

HEINZ, DANIEL-KAPOVITS, GEZA: SAINT MARGIT GYMNASIUM
Citation: Metszet, Vol 17, No 6 (2020), pp 80-85, DOI: 10.33268/Met.2020.6.13

water, a flat roof which is also a football pitch program and the number of people are limited, we show the structure regarding the thermal and all the issues which arrive from the new on the hillside and the architect's attitude and shell of the building, protection against ground technologies.

BECKER, GÁBOR: FROM ANCIENT TIMES TO THE PRESENT - BYTES FROM THE PAST AND PRESENT OF PREFABRICATION Citation: Metszet, Vol 11, No 6 (2020), pp 86-91, DOI: 10.33268/Met.2020.6.14

$\begin{array}{ll}\text { steel structures of the modern age. Nowas ancient Greek temples and medieval } & \text { from America to Japan prefabrication is }\end{array}$

HUNYADI, ZOLTÁN: ENFORCEMENT OF ACOUSTIC QUALITY STANDARDS FOR RESIDENTIAL BUILDINGS IN THE LIGHT OF CURRENT REQUIREMENTS

Citation: Metszet, Vol 11, No 6 (2020), pp 92-97, DOI: 10.33268/Met.2020.6.15

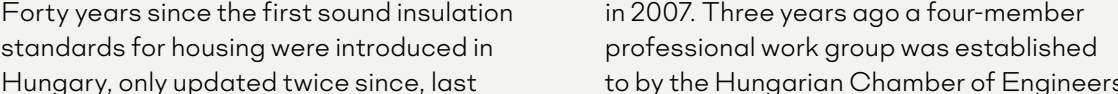

their findings have not been acted upon even to by the Hungarian Chamber of Engineers, noise events suggest it is time to re-review.

MESTERHÁZY, BEÁTA: THE MOST IMPORTANT EXPERIENCES GAINED DURING OPERATION OF THE BME BUILDING

Citation: Metszet, Vol 17, No 6 (2020), pp 98-103, DOI: 10.33268/Met.2020.6.16

Since the mid-1970s but has had a Building tests, results have been puble

Acoustics Laboratory working closely in 1995 and 2011 emphasis was placed on the

covers roofs and provides an overview of partnership with the department of building
structures. Aside from educational research
establishtion of specific walls structures to

TAKÁCS, LAJOS - SZIKRA, CSABA - ZSITVA, ATTILA: FIRE SPREAD PREVENTION FOR ELEVATIONS WITH NON-FIRE RATED GLAZING

Citation: Metszet, Vol 11, No 6 (2020), pp 104-109, DOI: 10.33268/Met.2020.6.17

fire resistant is possible, this path is rarely equipment - window sprinklers - without a fire

$\begin{aligned} & \text { chosen due to its cost. According to the } \\ & \text { current National Fire Protection Regulations, }\end{aligned}$
resistance limit value can only be designed
anstalled on the basis of a real-scale,

ffective fire test. Our article looks for an answer for glazed structures with built-in fire
extinguishers and curtain walls with limited

TAKÁCS, LAJOS - SZIKRA, CSABA: FLOW TESTING OF DOCKING GATES TO HALL BUILDINGS TAKING INTO ACCOUNT HEAT AND SMOKE EXTRACTION

Citation: Metszet, Vol 11, No 6 (2020), pp 110-115, DOI: 10.33268/Met.2020.6.18

This article examines the heat and smoke The geometry and materials used in the

buildings at docking gates. Airflow rates

construction of docks, how this can be
numerically simulated to assist in the

fire. The legal background and implications design process for movement of air during

ocking areas and their

MEDVEY, BOLDIZSÁR: FOLK SCIENCE STUDENT CIRCLE USABILITY OF RESEARCH SURVEYS Citation: Metszet, Vol 11, No 6 (2020), pp 116--119, DOI: 10.33268/Met.2020.6.19

Contemporary adobe architecture seems some pioneering examples do not require

building materials. Brave moves to exposen

adobe structures are made possible when

these pical additives. Seeing the success of

existing buildings to see how they function as

the fare without their ominous hats and boots. research of the Folk Science Student Circle.

a building material use type and how would 